\title{
Evaluation of Bioactive Compounds in Nutrition Physiology
}

(D)

Yıkmış $\mathrm{S}^{1}{ }^{*}$, Kağan $\mathrm{N}^{2}$, Atan R.M ${ }^{3}$ and Alpaslan $\mathrm{M}^{4}$

To cite this article

: Yıkmış S, Kağan N, Atan R.M, Alpaslan M (2018) Evaluation of Bioactive Compounds in

Nutrition Physiology. Int. J. Agr. Life. Sci, 4(1), 232-235, DOI: 10.22573/spg.ijals.018.s12200089

To link to this article

: https://doi.org/10.22573/spg.ijals.018.s12200089

Copyright

: ๑ 2018 Yıkmış S et al. This is an Open Access article distributed under the terms of the Creative Commons Attribution License (http://creativecommons.org/licenses/by/4.0/), which permits unrestricted use, distribution, and reproduction in any medium, provided the Original work is properly cited.

Data Availability Statement : All relevant data are within the paper and its Supporting Information files.

Funding

: The author(s) received no specific funding for this work.

Competing Interests

: The authors have declared that no competing interests exist. 
REVIEW ARTICLE

\title{
Evaluation of Bioactive Compounds in Nutrition Physiology
}

Yıkmış $\mathrm{S}{ }^{*}$, Kağan $\mathrm{N}^{2}$, Atan R.M ${ }^{3}$ and Alpaslan $\mathrm{M}^{4}$

1. Lecturer, Namık Kemal University, Department of Nutrition and Dietetics, Turkey

2. M.Sc., Namık Kemal University, Department of Nutrition and Dietetics, Turkey

3. Professor, Namık Kemal University, Department of Nutrition and Dietetics, Turkey

4. M.Sc., Namık Kemal University, Department of Nutrition and Dietetics, Turkey

*Author to whom correspondence should be addressed; E-Mail: syikmis@nku.edu.tr

Received: Mar 2018 / Accepted: Mar 2018/ Published: Mar 2018

\begin{abstract}
Many peptides released from animal or plant proteins in vitro or in vivo have therapeutic functions in humans beyond bioactivity and adequate nutrition. Different health effects have been attributed to foodborne peptides, including antimicrobial properties, blood pressure lowering (ACE inhibitor) effects, cholesterol lowering ability, antithrombotic and antioxidant activities, increased mineral absorption, immunomodulatory effects and opioid activities. For this reason, nutritional counseling practices deal with these issues. Specific protein fractions with therapeutic effects on body function and health are termed biological peptides and have been shown to have a direct positive effect on health. Angiotensin I-converting enzyme (ACE) is a carboxy-dipeptidyl metallopeptidase associated with the renin angiotensin system that regulates the production of angiotensin II from vasoconstrictor angiotensin-II and peripheral blood pressure that catalyzes the inactivation of vasodilator bradykinin. For this reason, the ACE inhibitor substance in the diet may inhibit hypertension by inhibiting the renin-angiotensin system. Milk proteins are now the main source of bioactive peptides. Such peptides are seen as natural and non-effective alternatives to drugs in the treatment of hypertension. The natural consumption of biological peptides will not be expected to cause side effects of synthetically produced drugs used to control hypertension. Therefore, it can be used as a powerful functional food additive and the ACE inhibitor is a natural and healthy alternative to drugs.

Keywords: Bioactive peptides, ACE inhibitors, Antihypertensive effect
\end{abstract}

\section{INTRODUCTION}

The role of proteins as physiologically active components in the diet is increasingly recognized. Naturally, most of the proteins that appear in raw foodstuffs apply physiological effects directly or in vitro or in vivo on enzymatic hydrolysis. In recent years, it has come to the conclusion that dietary proteins are rich in biologically active peptide sources. Physiologically active peptides are known to be produced from various food proteins during gastrointestinal digestion and during fermentation of foodstuffs with lactic acid bacteria (Korhonen \& Pihlanto, 2006).

Bioactive peptides

By definition, "nutrient-derived bioactive peptides" refers to peptides of different plant or animal origin that may have regulatory functions in the human system beyond normal and adequate nutrition (Hartmann \& Meisel, 2007). It is also defined as specific protein fractions with bioactive peptides, body functions and health-improving effects. Bioactive peptides inactive in the main protein sequence, hydrolysis with digestive enzymes from precursor proteins; fermentation through proteolytic starter cultures; It occurs during proteolysis by enzymes originating from plants or microorganisms (Koçak \& Şanlı, 2016). Peptides that are inactive in the content of foods are activated by the hydrolysis of proteins. Peptides that become bioactive have regulatory effects through hormone functions (Tez \& Aksay, 2010). Once bioactive peptides are taken with food or produced in the intestine, they are again absorbed by the intestinal target parts and reach the peripheral organs (Gür, Güzel, Öncül, Yıldırım, \& Yıldırım, 2010). Bioactive peptides can bioactivity in the small and large intestine by getting rid of food proteins along the intestine. However, it is known that most of the food proteins are destroyed during passage through the small intestine and microbial activity occurs mainly in the large intestine, so that release by the microbial enzymes during digestion is given to the proteins reaching this region of the intestine (Möller, Scholz-Ahrens, Roos, \& Schrezenmeir, 2008).

Bioactive peptides generally contain 3 to 20 amino acid residues and their bioactivity is based on the amino acid composition and location in the peptide-forming amino acid sequence. These peptides are not active in the sequences of the parent proteins but can be released by enzymatic hydrolysis by proteolytic enzymes during gastrointestinal digestion, by safe bacteria such as lactobacilli during fermentation or food processing. To create a positive health effect, bioactive peptides must cross the GI barrier and live an enzyme degradation (Mora, Aristoy, \& Toldrá, 2016).

Depending on the sequence of amino acids, these peptides may exhibit a variety of activities including mineral binding, immunomodulatory, antimicrobial, antioxidant, antithrombotic, hypocholesterolemic and antihypertensive effects.

Examples of bioactive peptides obtained from grains;

- Antioxidant activity: sardine oil, soya, milk (casein and B-lactoglobulin) egg whites

- Antithrombotic: milk (casein, lactoferrin)

- Hypocholesterolemic: soy, milk (B-lactoglobulin)

- Hypotriglyceridemic: blood 
- Antiobesity: soy, milk (casein)

Bioactive peptides are obtained by hydrolysis or fermentation from the abovementioned animal and vegetable materials such as milk and dairy products, eggs, soy bean, blood, gelatin, meat and fish (Şimşek \& Kılıç, 2016). The most commonly used method is enzymatic hydrolysis. Pepsin, trypsin and chymotrypsin enzymes are used for enzymatic hydrolysis (Gür et al., 2010).

Bioactive peptides can be used as ingredients for functional foods or nutraceuticals due to their potency and safety profile. However, milk proteins are now the main source of diverse bio-functional peptides and it has been proven that daily intake of milk and dairy products is physiologically important for both newborns and adults (Erdmann, Cheung, \& Schröder, 2008).

\section{ACE inhibitors}

In recent years, some food proteins have been identified as sources of angiotensin l-converting enzyme (ACE) inhibitor peptides and are currently the best known class of bioactive peptides.(Erdmann et al., 2008) ACE is the most common dipeptidyl carboxypeptidase, which is bound to membranes in mammals, usually in vascular endothelial cells (Mora et al., 2016).

The angiotensin I-converting enzyme (ACE) catalyzes the conversion of angiotensin I to the potent vasoconstrictor angiotensin II and plays an important physiological role in regulating blood pressure and fluid and salt balance in mammals (Hartmann \& Meisel, 2007). ACE also inactivates the antihypertensive vasodilator bradykinin (Mora et al., 2016).

ACE inhibitors reduce the breakdown of bradykinin, a potent vasodilator, by raising the level of renin in the plasma to a great extent. In this way, the whole of the cardiovascular system undergoes arterial vasodilatation due to the decrease of angiotensin II levels, reducing total peripheral vascular resistance and reducing blood pressure. ACE inhibitors inhibit the formation of hypertension by blocking the effect of the enzyme by binding competitively to ACE. Especially in the C-terminal region, it has been determined that there are strong antihypertensive effects of peptides containing amino acids of proline, lysine and arginine (Erdmann et al., 2008; Kim \& Wijesekara, 2010).

Hypertension or high blood pressure is one of the major independent risk factors for cardiovascular disease, which is a leading cause of morbidity and mortality. The pathogenesis of hypertension has shown that angiotensin converting enzyme plays an important physiological role in the regulation of blood pressure (Yu, Zhang, \& Zhang, 2016). Therefore, ACE inhibitory substances in foods, inhibiting the renin-angiotensin system, when absorbed into the bloodstream from the intestine, can suppress hypertension (Okamoto et al., 1995).

Many side effects, such as hypotension, elevated potassium levels, decreased renal function, cough, angioedema, edema, skin rashes, and fetal abnormalities have been associated with synthetic ACE inhibitor drugs (Anderson \& Moore, 2004). However, these peptides will not be expected to naturally cause consumption, problems associated with synthetically produced drugs used to control hypertension, such as coughs in serum lipid metabolism, and the like (Sciences, Milchforschung, Chemie, Fitzgerald, \& Meisel, 2018).

Nowadays, milk, fish, meat, eggs, soybeans, corn, wheat, and algae as many food types, there are hundreds ACE inhibitor peptides identified in many protein hydrolysates (Mora et al., 2016). Because of this direct link between ACE and hypertension, many drugs with inhibitors such as captopril, enalapril, alasepril and lisinopril have been shifted to finding natural and reliable investigations due to many side effects such as a cough, various skin problems, angioneerative edema, to prevent ACE activity. In vitro and in vivo studies have been carried out on the ACE inhibition effect of proteins obtained from milk and dairy products, vegetable proteins such as soybean, pea, lentil and other sea products from algae (Gao, Chang, Li, \& Cao, 2002; Kim \& Wijesekara, 2010; Wu, Liao, \& Udenigwe, 2017).

In a study, it was found that mice fed with ACE inhibitor-rich foods suppressed spontaneous hypertension. In vivo studies in patients with hypertension nutraceutically, foods with ACE inhibitor peptides may have an antihypertensive effect (Pihlanto, Virtanen, \& Korhonen, 2010; Seppo, Jauhiainen, Poussa, \& Korpela, 2003).

Antihypertensive peptides derived from dairy products

Fermented milky foods are a physiologically important peptide source that provides energy and nutrients as well as positive effects on the body's functions (Pihlanto, 2006; Tirelli, De Noni, \& Resmini, 2000).

Although animal and vegetable proteins contain bioactive sequences, milk proteins are shown as the main source of bioactive peptides. Milk proteins, casein and whey proteins are a good bioactive peptide source that can positively affect body function and ultimately affect health (Rasika et al., 2015). In addition, casein and whey are rich in ACE inhibitors (Ra, Ege, \& Fak, 2013). Among the different bioactive peptides, ACE inhibitor peptides are the most thoroughly studied group. A number of ACE-inhibitor peptides have been identified from different fermented milk products such as yoghurt (Rasika et al., 2015).

Bioactive peptides derived from milk and dairy products have been reported to have various health benefits such as anticarcinogenic, weight management, antithrombotic, antioxidative, immunomodulatory and antihypertensive properties (Pihlanto, 2006; Tirelli et al., 2000).

Meat-derived antihypertensive peptides

Meat proteins are hydrolyzed by proteolytic enzymes during fermentation and storage, thus producing bioactive peptides from fermented meat products (Arihara, 2006). The amount of bioactive peptides increases during ripening and storage of the meat after cutting (Şimşek \& Kılıç, 2016). Bioactive peptides have been isolated from digestive enzymes such as pepsin, trypsin and chymotrypsin in meat products. Several proteases from bacterial, animal and plant sources have also been used to produce bioactive peptides from meat sources (Ryan, Ross, Bolton, Fitzgerald, \& Stanton, 2011).

First, during fermentation of meat products, meat proteins are separated by peptides by endogenous enzymes. Protein degradation is not greatly affected by bacteria, as most bacteroids that develop in fermented meat products have poor proteolytic activity. Among the bioactive peptides derived from meat proteins, ACE inhibitor peptides are the most studied (Arihara, 2006).

Other foods antihypertensive peptides

In a study with pea, it was found that increasing the temperature from $25^{\circ} \mathrm{C}$ to $50^{\circ} \mathrm{C}$ led to an increase in ACE inhibitor and antioxidant activity (Siow \& Gan, 2013). Many bioactive peptides have been identified in fermented soy products that show ACE inhibitors, antithrombotic, surfactant and antioxidant 
properties (Gibbs, Zougman, Masse, \& Mulligan, 2004). Presence of ACE inhibitor peptides in corn produced by fermentation with maize wheat or rice bacteria and lactic acid bacteria has been detected (Kancabaş \& Karakaya, 2013). During fermentation of fermented soybean product Douchi, traditionally produced in China, the change in ACE inhibitory activity was investigated and activity increased over the two week fermentation period, but decreased over time (Wang, Li, Cheng, Yin, \& Li, 2013).

\section{CONCLUSIONS}

Within the group of bioactive peptides, antihypertensive peptides (ACE inhibitor) the ability to test their function in vitro on humans and animals and to test them in different foods. These peptides can be used as powerful functional food additives and provide a natural and healthy alternative to ACE inhibitor drugs.

\section{REFERENCES}

1. Anderson, G. H., \& Moore, S. E. (2004). The Emerging Role of Dairy Proteins and Bioactive Peptides in Nutrition and Health Dietary Proteins in the Regulation of Food Intake and Body Weight in Humans. Journal of Nutrition, 134(4), 974-979. https://doi.org/10.1128/JB.188.5.1691

2. Arihara, K. (2006). Strategies for designing novel functional meat products. Meat Science, 74(1), $219-229$. https://doi.org/10.1016/j.meatsci.2006.04.028

3. Erdmann, K., Cheung, B. W. Y., \& Schröder, H. (2008). The possible roles of food-derived bioactive peptides in reducing the risk of cardiovascular disease. Journal of Nutritional Biochemistry, 19(10), 643-654. https://doi.org/10.1016/j.jnutbio.2007.11.010

4. Gao, D., Chang, T., Li, H., \& Cao, Y. (2002). African journal of biotechnology. African Journal of Biotechnology (Vol. 9). Academic Journals. Retrieved from https://www.ajol.info/index.php/ajb/article/view/125800

5. Gibbs, B. F., Zougman, A., Masse, R., \& Mulligan, C. (2004). Production and characterization of bioactive peptides from soy hydrolysate and soy-fermented food. Food Research International, 37(2), 123-131. https://doi.org/10.1016/J.FOODRES.2003.09.010

6. Gür, F., Güzel, M., Öncül, N., Yıldırım, Z., \& Yıldırım, M. (2010). Süt Serum Proteinleri ve Türevlerinin Biyolojik ve Fizyolojik Aktiviteleri. Akademik GIda, 8(1), 23-31.

7. Hartmann, R., \& Meisel, H. (2007). Food-derived peptides with biological activity: from research to food applications. Current Opinion in Biotechnology, 18(2), 163-169. https://doi.org/10.1016/j.copbio.2007.01.013

8. Kancabaş, A., \& Karakaya, S. (2013). Angiotensin-converting enzyme (ACE)-inhibitory activity of boza, a traditional fermented beverage. Journal of the Science of Food and Agriculture, 93(3), 641-645. https://doi.org/10.1002/jsfa.5883

9. Kim, S.-K., \& Wijesekara, I. (2010). Development and biological activities of marine-derived bioactive peptides: A review. Journal of Functional Foods, 2(1), 1-9. https://doi.org/10.1016/J.JFF.2010.01.003

10. Koçak, A., \& Şanlı, T. (2016). Süt Proteini Kaynaklı ACE-İnhibitör Peptitleri: Oluşumu, Etki Mekanizması ve Biyoyararlılıkları. Gida / the Journal of Food, 41, 275-283. https://doi.org/10.15237/gida.GD16024

11. Korhonen, H., \& Pihlanto, A. (2006). Bioactive peptides: Production and functionality. International Dairy Journal, 16(9), 945-960. https://doi.org/10.1016/j.idairyj.2005.10.012

12. Mora, L., Aristoy, M.-C., \& Toldrá, F. (2016). Bioactive Peptides in Foods. Encyclopedia of Food and Health, 395-400. https://doi.org/10.1016/B978-0-12-384947-2.00067-2

13. Möller, N. P., Scholz-Ahrens, K. E., Roos, N., \& Schrezenmeir, J. (2008). Bioactive peptides and proteins from foods: Indication for health effects. European Journal of Nutrition, 47(4), 171-182. https://doi.org/10.1007/s00394-008-0710-2

14. Okamoto, A., Hanagata, H., Matsumoto, E., Kawamura, Y., Koizumi, Y., \& Yanagida, F. (1995). Angiotensin I Converting Enzyme Inhibitory Activities of Various Fermented Foods. Bioscience, Biotechnology, and Biochemistry, 59(6), 1147-1149. https://doi.org/10.1271/bbb.59.1147

15. Pihlanto, A. (2006). Bioactive peptides: Production and functionality. International Dairy Journal, 16(9), 945-960. https://doi.org/10.1016/J.IDAIRYJ.2005.10.012

16. Pihlanto, A., Virtanen, T., \& Korhonen, H. (2010). Angiotensin I converting enzyme (ACE) inhibitory activity and antihypertensive effect of fermented milk. International Dairy Journal, 20(1), 3-10. https://doi.org/10.1016/J.IDAIRYJ.2009.07.003

17. Ra, H., Ege, U., \& Fak, Z. (2013). Gida Kaynaklı Antihïpertensif Peptïtlerïn Bïyoyararliliği Üretïmỉ Ve llaç Bioavailability , Production and Possibility of Alternative To Drug of Food-Derived Antihypertensive Peptides, 38, 167-174.

18. Rasika, D. M. D., Ueda, T., Jayakody, L. N., Suriyagoda, L. D. B., Silva, K. F. S. T., Ando, S., \& Vidanarachchi, J. K. (2015). ACE-inhibitory activity of milk fermented with saccharomyces cerevisiae $\mathrm{k} 7$ and lactococcus lactis subsp. lactis nbrc 12007. Journal of the National Science Foundation of Sri Lanka, 43(2), 141-151. https://doi.org/10.4038/jnsfsr.v43i2.7942

19. Ryan, J. T., Ross, R. P., Bolton, D., Fitzgerald, G. F., \& Stanton, C. (2011). Bioactive peptides from muscle sources: Meat and fish. Nutrients, 3(9), 765-791. https://doi.org/10.3390/nu3090765

20. Sciences, L., Milchforschung, Ė., Chemie, Ė., Fitzgerald, R. J., \& Meisel, H. (2018). Milk protein-derived peptide inhibitors of angiotensin-Iconverting enzyme, (2000), 33-37.

21. Seppo, L., Jauhiainen, T., Poussa, T., \& Korpela, R. (2003). A fermented milk high in bioactive peptides has a blood pressure-lowering effect in hypertensive subjects. The American Journal of Clinical Nutrition, 77(2), 326-30. Retrieved from http://www.ncbi.nlm.nih.gov/pubmed/12540390

22. Siow, H.-L., \& Gan, C.-Y. (2013). Extraction of antioxidative and antihypertensive bioactive peptides from Parkia speciosa seeds. Food Chemistry, 141(4), 3435-3442. https://doi.org/10.1016/j.foodchem.2013.06.030

23. Şimşek, A., \& Kılıç, B. (2016). Et KaynaklBiyoaktiffPeptïtler VeFonksiyoneÖzellikleri. Gida / the Journal of Food, 41, $267-274$. https://doi.org/10.15237/gida.GD16013

24. Tez, S., \& Aksay, S. (2010). Mercimek proteïni konsantresĩ ve hïdrolizatinin bazi fonksïyonel ve bïyoaktif özelliklerïnïn inncelenmesii.

25. Tirelli, A., De Noni, I., \& Resmini, P. (2000). Bioactive Peptides in Milk Products. Journal of Food Technology in Africa, 5(1). https://doi.org/10.4314/jfta.v5i1.19254

26. Wang, H., Li, Y., Cheng, Y., Yin, L., \& Li, L. (2013). Effect of the Maillard Reaction on Angiotensin I-Converting Enzyme (ACE)-Inhibitory Activity of Douchi During Fermentation. Food and Bioprocess Technology, 6(1), 297-301. https://doi.org/10.1007/s11947-011-0596-5

27. $\mathrm{Wu}$, J., Liao, W., \& Udenigwe, C. C. (2017). Revisiting the mechanisms of ACE inhibitory peptides from food proteins. Trends in Food Science \& Technology, 69, 214-219. https://doi.org/10.1016/J.TIFS.2017.07.011. 
International Journal of Agricultural and Life Sciences- IJALS (2018), Volume 4 (1) pp.232-235

http://dx.doi.org/10.22573/spg.ijals.018.s12200089

Available online at http://www.skyfox.co

28. Yu, J., Zhang, S., \& Zhang, L. (2016). Amadori compounds as potent inhibitors of angiotensin-converting enzyme (ACE) and their effects on anti-ACE activity of bell peppers. Journal of Functional Foods, 27, 622-630. https://doi.org/10.1016/j.jff.2016.10.017

How to cite this article

Yıkmış S, Kağan N, Atan R.M, Alpaslan M (2018) Evaluation of Bioactive Compounds in Nutrition Physiology. Int. J. Agr. Life. Sci, 4(1), 232-235, DOI: 10.22573/spg.ijals.018.s12200089

\section{CONFLICTS OF INTEREST}

"The authors declare no conflict of interest".

(c) 2018 by the authors; Published by SKY FOX Publishing Group, Tamilnadu, India. This article is an open access article distributed under the terms and conditions of the Creative Commons Attribution license (http://creativecommons.org/licenses/by/4.0/). 